\title{
HEAT TRANSFER MODELLING IN GREEN FAÇADES
}

\author{
FABIANA CONVERTINO* \\ Department of Agricultural and Environmental Science, University of Bari, Italy
}

\begin{abstract}
Making green urban environments through the application of the vertical green façades is an interesting new challenge in view of the growing sustainability of cities. Several advantages have been recognized for this type of passive technology. Inhabitants, buildings and cities are all recipients of these benefits. Due to their potential, an in-depth knowledge of the energy functioning of green façades and, consequently, their conscious use has become essential. This study traces a path for the energy analysis and modelling of green façade systems. Heat fluxes were identified and described by using a mathematical methodology and with the support of experimental data. The energy balance approach was followed. The most significant heat and mass transfer mechanisms were deepened and modelled. Convective, radiative and evapotranspirative exchanges were considered. Thanks to this strategy, the surface energy budget at the external building surface was evaluated. A comparison between the energy behaviour of a green façade and that of a bare wall was carried out. A measurement campaign relative to an experimental green façade realized at the University of Bari allowed also the implementation of realistic data. It was observed that the covered wall, behind the vegetation layer, gained $88 \%$ less energy than the bare wall during daytime in the summer. The findings demonstrated, with knowledge of the facts, that the green façades applied to buildings provide significant advantages in Mediterranean areas. In perspective, this study could be further developed through the writing of codes for the energy simulation of building equipped with green façades.

Keywords: green infrastructures, building envelope, vertical greening, energy balance, energy saving.
\end{abstract}

\section{INTRODUCTION}

The climatic and environmental emergency is now a fact and can no longer be ignored. All human activities, in every sector, must be oriented towards increasing sustainability. The constructive activities and the building sector have a great negative impact; thus, a sustainable turn can produce significant improvements.

Concerning this, a great opportunity is provided by the spread of the urban green infrastructures (UGIs) [1], [2]. The concept of UGI is wide and refers to several planned and unplanned solutions which bring vegetation inside cities [3]. Vegetation is, in fact, the key to solve numerous environmental problems and to improve the quality of urban areas.

A promising way, under many points of view, to integrate vegetation into urban contexts is its application on buildings surfaces [4]. These kinds of UGIs belong to two main groups of technological solutions: green roofs and vertical green systems (VGS) [5]. In the past few years, green roofs were the most studied and applied typology. Recently, VGSs received increasing research interest and their applications in cities multiplied. An indisputable advantage of using VGSs instead of green roofs is linked to the surfaces available in cities. The overall vertical surface is certainly wider than the horizontal one. However, concerning VGSs, other research contributions are needed to fill some gaps, especially to clarify their real performance and the most relevant influencing factors [6].

Many technical solutions are included in the expression VGSs. In any case, it indicates that a layer of vegetation covers the vertical walls of building. Plants can be directly attached to the wall or placed at a certain distance from it. They can be rooted into the ground or in pots and supported by metal structures (green façades) or in modular panels (green walls)

* ORCID: http://orcid.org/0000-0002-3799-6038 
[7], [8]. Beyond the multiple available technical solutions, what needs to be highlighted is that VGSs are passive sustainable envelope technologies providing various kinds of positive contributions. The reduction of the urban heat island effect, the lowering of the carbon dioxide emissions and the rainwater retention are among the VGSs benefits at the urban scale. At the same time, VGSs enhance thermal performance of buildings, contributing to energy saving and human comfort. The application of greenery systems, as the recovery of the traditional bioclimatic architecture and the careful choice of constructive materials properties can contribute to the improvement of microclimatic conditions and human wellbeing [9]-[15].

This study focuses on a particular type of VGSs: the indirect green façade (GF). These GFs can be considered as double skin façades. In this case the second skin is the green layer of vegetation. This consists of evergreen or deciduous plants, climbing from below or cascading from above. Generally, a net is placed to assist the growth of the plants. This supporting structure allows to create an air gap between the building wall and the vegetation layer, since it stands at a certain distance from the building envelope. As other VGSs, GFs are a means of passive climate control in buildings. In fact, they are able to reduce the building heat transfer with the external environment. Many environmental and constructive factors influence the thermal performance of GFs: the climate, the building features and the plant characteristics are the most significant ones [16]-[18]. The positive contributions to the energy performance of the building envelope provided by the GF system can be summarized into three main functions. The green layer applied to building acts as a shading barrier during daytime [19]-[21]. At the same time, the vegetation, together with the air gap, increases the building envelope thermal insulation [22], [23]. A significant additional benefit is provided by the evapotranspiration of the plants and of the ground [24], [25]. As consequences, a building equipped with a GF has lower surface and air temperature and needs less energy for cooling, in summer [26]-[28]. In wintertime, the increased insulation and the effects of thermal and wind barrier provide the main benefits [29]-[31].

Evaluation of GFs performance mainly comes from empirical measurements on real scale buildings or small experimental blocks. In fact, a significant gap, concerning GFs, is the poor availability of energy models and simulation tools specific for them. Specific GFs tools implemented in building energy simulation programs would allow to simulate the energy behaviour of buildings equipped with GFs and, thus, to analyse them under different conditions and for long time periods. In this way, GFs would be designed in the best way and their energy functioning could be forecasted.

The design of simulation tools needs the energy model of a GF. The GF modelling implies that all the heat and mass transfer mechanisms occurring at each layer must be defined [32]-[35]. Heat fluxes due to radiation, convection and evapotranspiration are the main ones.

This paper focuses on the energy behaviour of the wall in the GF system, compared to a bare one. The influence of the presence or not of the green layer is clear by analysing the energy balance at the external surface of the two walls. In this research, radiative and convective energy transfer were mathematically defined and calculated for the two envelope solutions. The effect of the evapotranspiration, which is the most specific of a GF, can be read in the air characteristics near the GF system, which are different from those near the bare wall. Experimental data were gathered and used in calculations. The different energy behaviour of the walls was emphasized during summer. The surface energy budget was analysed with particular attention to the period of the day. 


\section{MATERIALS AND METHODS}

Heat fluxes occurring at the external surface of a green façade system and of a bare wall, used as control, were studied. Three layers were identified to schematize these envelope solutions and the heat transfer mechanisms: the bare wall (BW), the green layer (GL) and the covered wall $(\mathrm{CW})$, which stands behind the vegetation in the GF system.

Heat fluxes at the external surface of the BW and of the CW were evaluated. Radiative exchanges in the solar wavelength range and in the IR longwave range, and convective heat flow were determined.

Data collected during a measurement campaign concerning an experimental green façade were implemented in calculations.

The calculated heat fluxes at the external surface of these two technological solutions allow to highlight their different energy behaviours and the possible advantages deriving from the application of GFs in the Mediterranean climate.

\subsection{Experimental set up}

The experimental data used in the energy modelling have been collected at the experimental centre of the University of Bari, in Valenzano (Italy), where a measurement campaign is still in progress since 2018. The experimental set up, which simulates a real building equipped with a green façade, consists of a block, having a rectangular plane. Its south facing wall was studied. This was made of perforated bricks, held together with cement mortar, and completed with a white plaster external finishing. Such constructive solution was chosen to reproduce a typical external envelope used in the Mediterranean region. The south facing wall was divided into three parts: two parts provided with a green façade system and the last left bare as control (Fig. 1). The selected type of green façade was the indirect or double-skin one. The layer of vegetation was placed at $0.15 \mathrm{~m}$ from the external surface of the wall and, thus, an air gap was created between them. Plants of Rhyncospermum Jasminoides, an evergreen climbing species, were selected and an iron net was used to support their upward growth. Three plants were placed in pots, while other three were rooted directly into the ground.

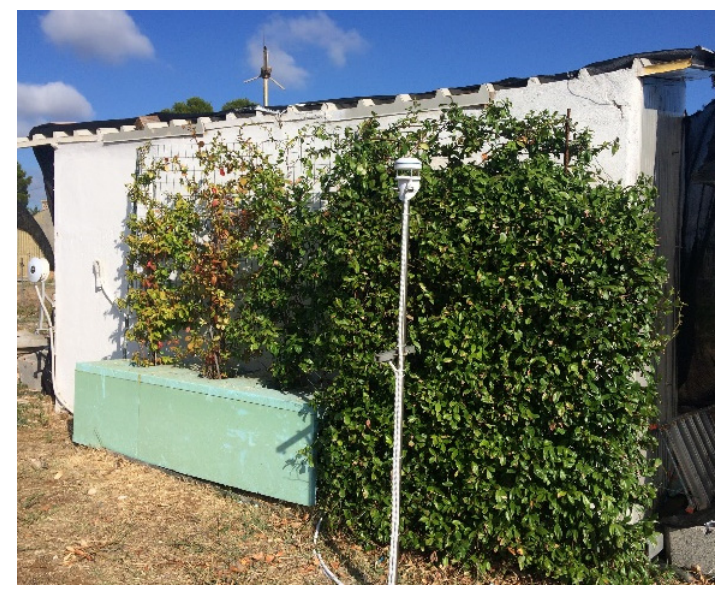

Figure 1: South facing wall and measurement instrumentation of the experimental set up. From right to left: green façade with plants rooted into the ground, green façade with plants in pots and bare wall (control). 
The experimental equipment consists of a meteorological station, three data loggers (CR10X and CR1000, Campbell, Logan, USA) and sensors for climatic parameters detection. A pyranometer (model 8-48, Eppley Laboratory, Newport, RI, USA) allowed to measure solar radiation normal to the wall; wind speed and direction were detected using a Wind Sentry anemometer (model 03002, R. M. Young Company, USA). HygroClip-S3 sensors (Rotronic, Zurich, Switzerland) were used to measure air temperature and relative humidity; walls surface temperature was measured by thermistors (Tecno.el s.r.l. Formello, Rome, Italy); the Apogee SI 400 IR radiometers (Logan, UT, USA) allowed to detect canopy temperature. Longwave infrared radiation was measured by means of a PIR pyrgeometer (Eppley Laboratory, Newport, RI, USA). An ultrasonic anemometer (ATMOS 22, METER Group, Pullman, WA, USA) was used to detect wind speed and direction near the wall. The measurements were taken every $60 \mathrm{~s}$, averaged every $15 \mathrm{~min}$ and stored in the data loggers.

\subsection{Modelling of the heat fluxes for bare and covered wall}

The heat fluxes occurring at the external surface of the BW and the CW were identified, described by mathematical relationships and evaluated by using the gathered experimental data.

The energy balance (B) for both the bare and the covered surfaces was written by including the different heat transfer mechanisms (Fig. 2). Positive values of B mean energy input in the surface.

For the external surface of BW, B was evaluated as:

$$
B_{b w}=E_{1}-E_{2}+\varepsilon_{w s}\left(R_{s k y}+R_{g}\right)-R_{e, b w}+C V_{b w, e a},
$$

where: $E$ terms refer to solar radiation, $R$ terms refer to longwave infrared (LWIR) radiation and $C V$ to convection.

The term $E_{1}\left(\mathrm{Wm}^{-2}\right)$ is the solar radiation on a vertical surface. $E_{2}\left(\mathrm{Wm}^{-2}\right)$ was calculated as a function of the solar reflectivity coefficient of the wall surface $\left(\rho^{s o l}{ }_{w s}\right)$

$$
E_{2}=\rho_{w s}^{s o l} E_{1} \text {. }
$$

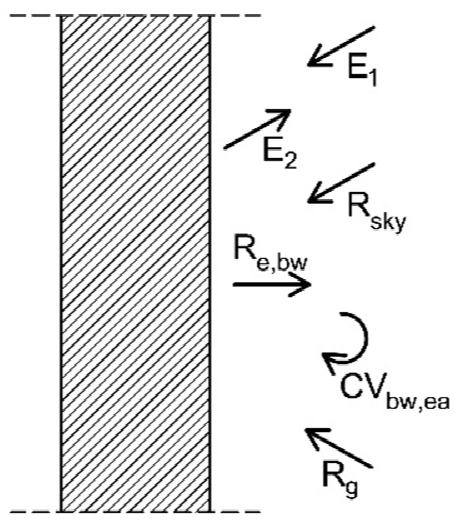

(a)

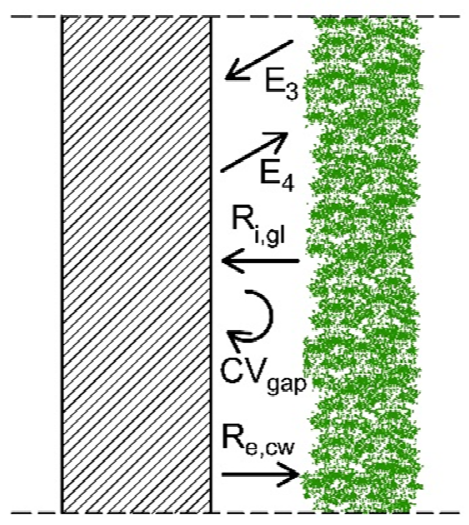

(b)

Figure 2: Heat fluxes at the external surface of (a) The BW; and (b) The CW. 
The LWIR terms were calculated by:

$$
\begin{gathered}
R_{s k y}=\sigma F_{s k y} T_{s k y}^{4}, \\
R_{g}=\varepsilon_{g} \sigma F_{g-v s} T_{g}^{4}, \\
R_{e, b w}=\varepsilon_{w s} \sigma T_{e, b w}^{4},
\end{gathered}
$$

where: $R_{s k y}, R_{g}$ and $R_{e, b w}\left(\mathrm{Wm}^{-2}\right)$ are the LWIR radiative energy coming from the sky and the ground and emitted by the external surface of the BW, respectively; $\sigma$ is the Stefan-Boltzmann constant equal to $5.67 \cdot 10^{-8} \mathrm{~W} \mathrm{~m}^{-2} \mathrm{~K}^{-4}, F_{\text {sky }}$ is the sky view factor between the sky and the building wall and $F_{g-v s}$ is the configuration factor between the ground and the vertical surface, $T_{s k y}, T_{g}$ and $T_{e, b w}(\mathrm{~K})$ are temperatures of the sky, of the ground and of the external surface of the BW, respectively; $\varepsilon_{g}$ and $\varepsilon_{w s}$ are the emissivity coefficient of the ground and of the BW external surface, respectively.

The convective heat transfer at the external surface of the BW was calculated by:

$$
C V_{b w, e a}=h_{e}\left(T_{e a}-T_{e, b w}\right),
$$

where $h_{e}\left(\mathrm{Wm}^{-1} \mathrm{~K}^{-1}\right)$ is the external convective coefficient and $T_{e a}(\mathrm{~K})$ is the external air temperature.

For the external surface of the $\mathrm{CW}, \mathrm{B}$ is:

$$
B_{c w}=E_{3}-E_{4}+\varepsilon_{w s} R_{i, g l}-R_{e, c w}+C V_{g a p} .
$$

The solar radiation terms were calculated by:

$$
\begin{aligned}
& E_{3}=\tau_{g l}^{s o l} E_{1}, \\
& E_{4}=\rho_{w s}^{s o l} E_{3},
\end{aligned}
$$

where $\tau^{\text {sol }}{ }_{g l}$ is the solar transmissivity coefficient of the leaves in the GL.

The LWIR radiative energy fluxes were:

$$
\begin{gathered}
R_{i, g l}=\varepsilon_{g l} \sigma T_{i, g l}^{4}\left(1-\rho_{g l} \rho_{w s}\right)^{-1}, \\
R_{e, c w}=\varepsilon_{w s} \sigma T_{e, c w}^{4}\left(1-\left(\varepsilon_{w s} \rho_{g l}\right)\left(1-\rho_{g l} \rho_{w s}\right)^{-1}\right),
\end{gathered}
$$

where: $R_{i, g l}$ and $R_{e, c w}\left(\mathrm{Wm}^{-2}\right)$ are the LWIR radiative energy emitted by the inner side of the $\mathrm{GL}$ and by the external surface of the $\mathrm{CW}$, respectively; $T_{i, g l}$ and $T_{e, c w}(\mathrm{~K})$ are the temperatures of the inner side of the GL and of the external surface of the CW; $\varepsilon_{g l}$ and $\rho_{g l}$ are the leaves emissivity and reflectivity coefficients, respectively, and $\rho_{w s}$ is the reflectivity coefficient of the wall surface.

The convective heat flux was calculated as a function of the convective coefficient $h_{g a p}$ $\left(\mathrm{Wm}^{-1} \mathrm{~K}^{-1}\right)[33]$ :

$$
C V_{\text {gap }}=h_{\text {gap }}\left(T_{i, g l}-T_{e, c w}\right) .
$$

\section{RESULTS AND DISCUSSION}

The heat fluxes at the external surface of the BW and the CW were evaluated by using the aforementioned mathematical relationships and the experimental data. Calculations were performed for a period of three clear summer days (26-28 August 2019).

Concerning the BW, Fig. 3(a) shows the energy exchanged by means of the three mechanisms at the external surface. During daytime the solar radiation provides the most significant gain of energy. LWIR radiative and convective exchanges are often negative (energy losses) and these essentially allow to disperse energy. 
Similar considerations can be done referring to the energy fluxes at the external surface of the CW (Fig. 3(b)). However, in this case, the heat fluxes, especially the solar one, show lower values than the previous ones.

The surface energy budget for the BW and the CW were shown in Fig. 4. These two curves summarize the different behaviour of the two envelope solutions.

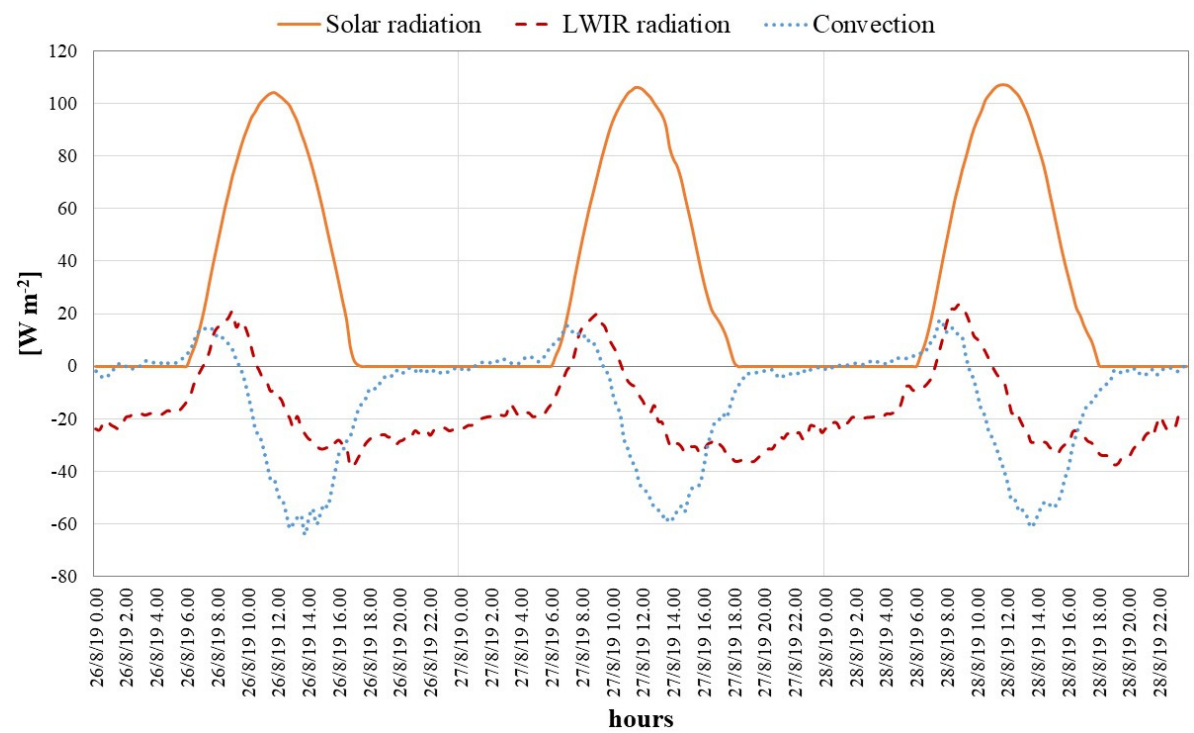

(a)

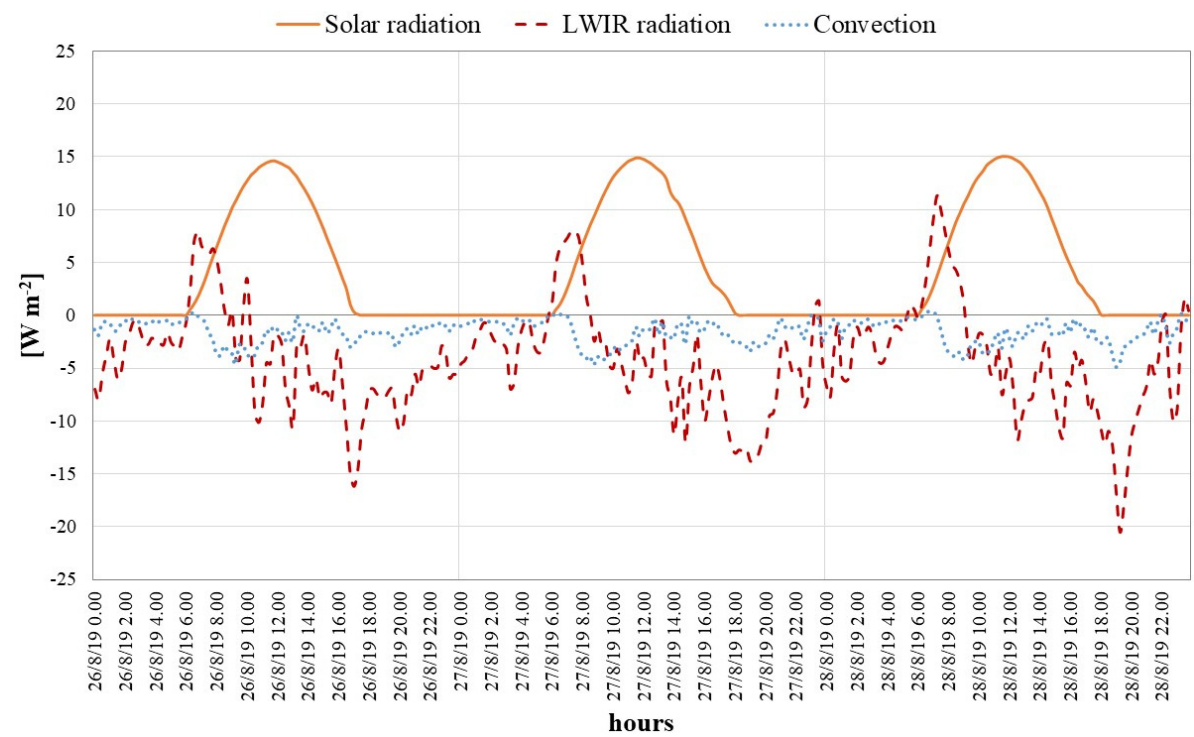

(b)

Figure 3: Calculated heat fluxes at the external surface of (a) The BW; and (b) The CW. Solar radiation, LWIR radiation and convection, 26-28 August, 2019. 


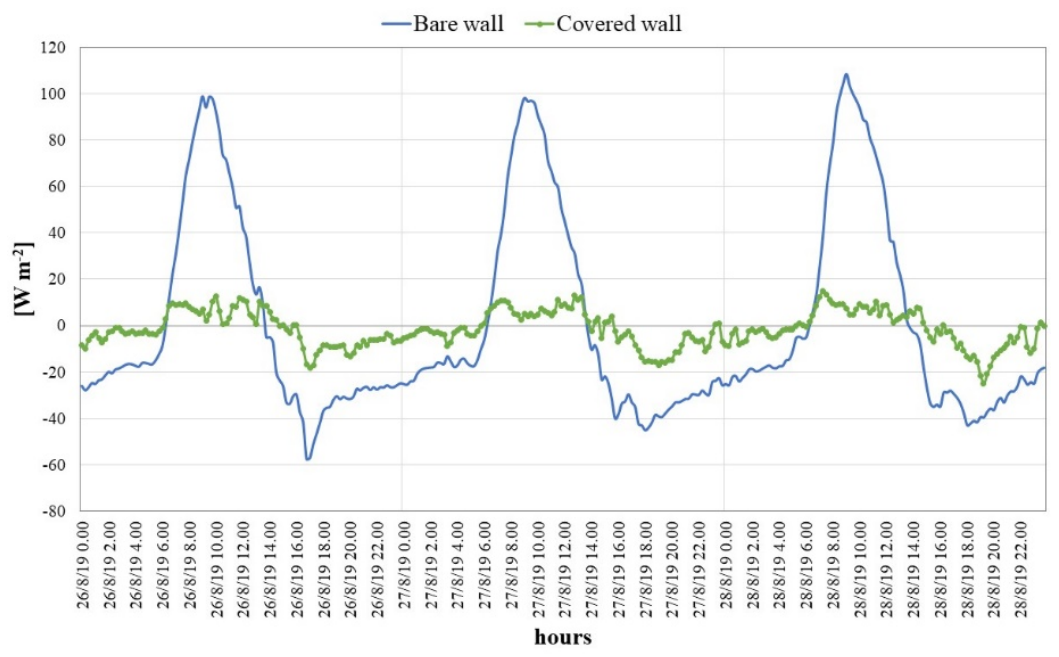

Figure 4: Energy balance at the external surface of the BW and the CW, 26-28 August 2019.

It is interesting to compare the energy functioning of the $\mathrm{BW}$ and the $\mathrm{CW}$, by focusing on the energy budget at their external surfaces (Fig. 5). In Fig. 5 the mean external air temperature was also plotted, to highlight the influence of this climatic parameter on the energy budget. During daytime, the energy gained by the BW was significantly higher than that gained by the CW (Fig. 5(a)). Similarly, the BW lost more energy than the CW at night-time (Fig. 5(b)). If compared to that of the BW, the range of energy variation for the $\mathrm{CW}$ was smaller, thus it was more stable. Concerning the energy budget for the all-day periods (Fig. 5(c)), the energy budget for the $\mathrm{CW}$ showed similar values for all the three days and it was always negative.

During daytime, the daily mean value of the energy budget for the BW was equal to $1.04 \mathrm{MJm}^{-2}$, while it was equal to $0.12 \mathrm{MJm}^{-2}$ for the $\mathrm{CW}$. This means that the $\mathrm{BW}$ gained $88 \%$ more energy than the $\mathrm{CW}$.

At night-time, the BW lost $0.98 \mathrm{MJm}^{-2}$, while the CW lost $0.25 \mathrm{MJm}^{-2}$.

Overall, the mean value of the energy budget for the all-day period was equal to 0.06 $\mathrm{MJm}^{-2}$ for the BW and to $-0.13 \mathrm{MJm}^{-2}$ for the $\mathrm{CW}$.

Concerning the evaluation of the energy performance of the GFs during warm seasons, these findings are significant. It was shown that the GL played a crucial role in reducing the heat fluxes and preventing the heating of the wall behind it. During warm days a BW gains energy, while a CW loses heat.

In the literature, the evaluation of the energy performance of the GFs was mainly based on the analysis of the surface temperature difference between the BW and the $\mathrm{CW}$ and on the energy balance at the internal surfaces of the walls. However, the findings of this research are consistent with those of the other studies. In fact, Jim and He [21] and Larsen et al. [36] showed that heat fluxes were significantly reduced in the $\mathrm{CW}$, compared to the $\mathrm{BW}$. Other authors found that the overall heat fluxes were generally negative for the $\mathrm{CW}$ and positive for the BW [35], [37], [38] and Chen et al. [37] showed that the CW was cooled especially through radiative heat exchanges. All these authors recognized the relevant advantages of the vertical greenings during summer. 
64 Urban Agriculture and City Sustainability II

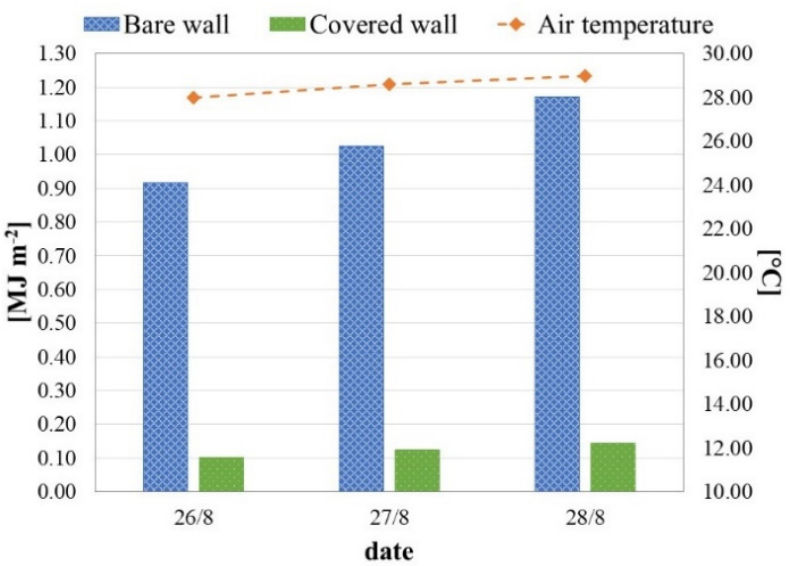

(a)

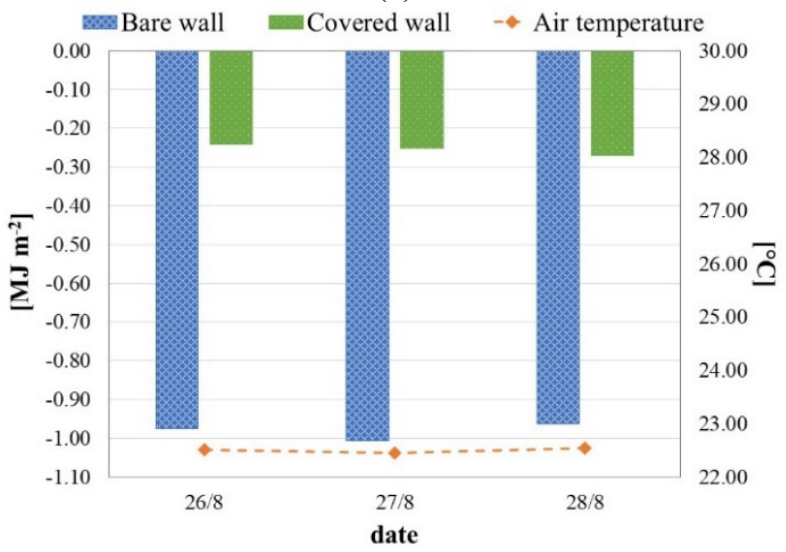

(b)

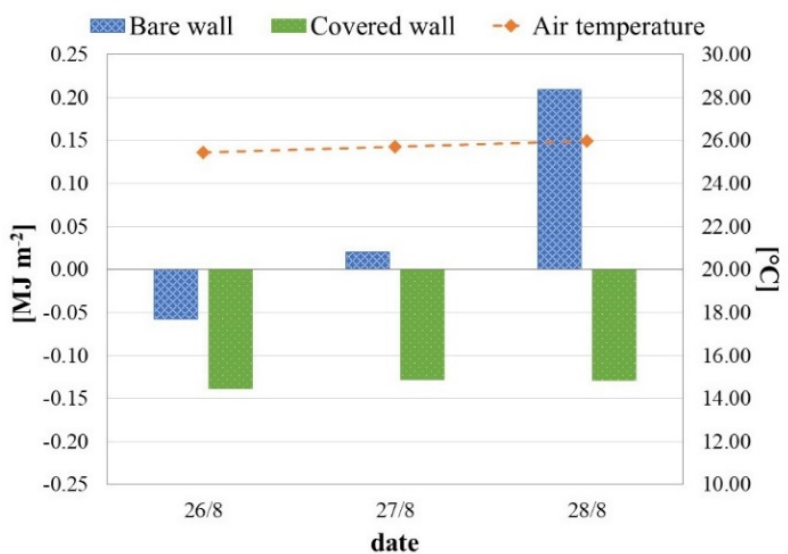

(c)

Figure 5: Energy budget at the external surface of the BW and the CW. (a) Daytime; (b) Night-time; and (c) All day. Mean external air temperature: 26-28 August, 2019. 


\begin{tabular}{clcl}
\hline & & \multicolumn{3}{c}{ Nomenclature } \\
\hline B & Balance of energy $\left(\mathrm{Wm}^{-2}\right)$ & $\rho^{\text {sol }}$ & Solar reflectivity coefficient \\
BW & Bare wall & $\sigma$ & Stefan-Boltzmann constant \\
CV & Convective heat transfer $\left(\mathrm{Wm}^{-2}\right)$ & & $\left(5.67 \cdot 10^{-8} \mathrm{~W} \mathrm{~m}^{-2} \mathrm{~K}^{-4}\right)$ \\
$\mathrm{CW}$ & Covered wall & $\tau^{\text {sol }}$ & Solar transmissivity coefficient \\
\cline { 3 - 4 } E & Solar radiative heat transfer $\left(\mathrm{Wm}^{-2}\right)$ & & \multicolumn{1}{c}{ Subscripts } \\
\cline { 2 - 4 } F & Configuration factor & $\mathrm{bw}$ & bare wall \\
$\mathrm{GF}$ & Green façade & $\mathrm{cw}$ & covered wall \\
$\mathrm{GL}$ & Green layer & $\mathrm{e}$ & external \\
$\mathrm{h}$ & Convective coefficient $\left(\mathrm{Wm}^{-1} \mathrm{~K}^{-1}\right)$ & $\mathrm{ea}$ & external air \\
LWIR & Longwave infrared & $\mathrm{e}, \mathrm{bw}$ & external surface of bare wall \\
$\mathrm{R}$ & LWIR radiative heat transfer $\left(\mathrm{Wm}^{-2}\right)$ & $\mathrm{e}, \mathrm{cw}$ & external surface of covered wall \\
$\mathrm{T}$ & Temperature $(\mathrm{K})$ & $\mathrm{g}$ & ground \\
$\mathrm{UGI}$ & Urban green infrastructure & $\mathrm{gl}$ & green layer \\
VGS & Vertical green system & $\mathrm{g}-\mathrm{vs}$ & from ground to vertical surface \\
$\varepsilon$ & Infrared emissivity coefficient & $\mathrm{i}, \mathrm{gl}$ & inner side of green layer \\
$\rho$ & Infrared reflectivity coefficient & $\mathrm{ws}$ & wall surface \\
\hline
\end{tabular}

\section{CONCLUSIONS}

Green façades can significantly improve the building energy performance thanks to the application of a layer of vegetation. The presence of plants has a positive influence on microclimatic conditions and on human comfort. In order to produce the best possible benefits and to allow their optimum design, energy models of GFs are needed.

This paper analysed the thermal behaviour of a wall in a GF system and highlighted the advantages compared to a bare wall, in summer clear sky days. Radiative and convective heat transfer were modelled. The evapotranspiration benefits were implicitly considered too. Data coming from an experimental GF, realized at the University of Bari, were recorded and used to calculate the effective heat fluxes at the external surface of the two walls. The solar radiative energy was found to be the most relevant for both walls, but significantly reduced in the covered wall. Convective and LWIR radiative exchanges mainly allowed to disperse energy. The surface energy budget at the outer side of the two building walls were evaluated and compared, taking into consideration the change during the day periods. This study demonstrated that the heat fluxes in a GF system were significantly reduced and that the covered wall was thermally more stable. The energy budget at the surface of the covered wall was negative, this means that it lost energy and that the wall heating was avoided. This energy behaviour has direct consequences on the energy saving for cooling in warm periods. Results obtained by this research can be a useful contribution to the modelling of the energy functioning of GFs and to the knowledge of the real advantages provided by them.

\section{REFERENCES}

[1] Bartesaghi Koc, C., C.P. Osmond, C.P. \& Peters, A., Evaluating the cooling effects of green infrastructure: A systematic review of methods, indicators and data sources. Solar Energy, 166, pp. 486-508, 2018. DOI: 10.1016/J.SOLENER.2018.03.008.

[2] Badiu, D.L., Nita, A., Iojă, C.I. \& Niţă, M.R., Disentangling the connections: A network analysis of approaches to urban green infrastructure. Urban Forestry and Urban Greening, 41, pp. 211-220, 2019. DOI: 10.1016/j.ufug.2019.04.013. 
[3] Mekala, G.D. \& Hatton MacDonald, D., Lost in transactions: Analysing the institutional arrangements underpinning urban green infrastructure. Ecological Economics, 147, pp. 399-409, 2018. DOI: 10.1016/J.ECOLECON.2018.01.028.

[4] Besir, A.B. \& Cuce, E., Green roofs and façades: A comprehensive review. Renewable and Sustainable Energy Reviews, 82, pp. 915-939, 2018.

DOI: 10.1016/j.rser.2017.09.106.

[5] Raji, B., Tenpierik, M.J. \& Van Den Dobbelsteen, A., The impact of greening systems on building energy performance: A literature review. Renewable and Sustainable Energy Reviews, 45, pp. 610-623, 2015. DOI: 10.1016/j.rser.2015.02.011.

[6] Zhao, X., Zuo, J., Wu, G. \& Huang, C., A bibliometric review of green building research 2000-2016. Architectural Science Review, 62(1), pp. 74-88, 2019. DOI: $10.1080 / 00038628.2018 .1485548$.

[7] Radić, M., Brković Dodig, M. \& Auer, T., Green façades and living walls - A review establishing the classification of construction types and mapping the benefits. Sustainability, 11, pp. 4579, 2019. DOI: 10.3390/su11174579.

[8] Medl, A., Stangl, R. \& Florineth, F., Vertical greening systems - A review on recent technologies and research advancement. Building and Environment, 125, pp. 227-239, 2017. DOI: 10.1016/j.buildenv.2017.08.054.

[9] Vox, G., Maneta, A. \& Schettini, E., Evaluation of the radiometric properties of roofing materials for livestock buildings and their effect on the surface temperature. Biosystems Engineering, 144, pp. 26-37, 2016.

DOI: 10.1016/j.biosystemseng.2016.01.016.

[10] Convertino, F., Di Turi, S. \& Stefanizzi, P., The color in the vernacular bioclimatic architecture in Mediterranean region. Energy Procedia, 126, pp. 211-218, 2017.

DOI: 10.1016/j.egypro.2017.08.142.

[11] Daemei, A.B., Azmoodeh, M., Zamani, Z. \& Khotbehsara, E.M., Experimental and simulation studies on the thermal behavior of vertical greenery system for temperature mitigation in urban spaces. Journal of Building Engineering, 20, pp. 277-284, 2018. DOI: $10.1016 /$ j.jobe.2018.07.024.

[12] Ghazalli, A.J., Brack, C., Bai, X. \& Said, I., Physical and non-physical benefits of vertical greenery systems: A review. Journal of Urban Technology, 26, pp. 53-78, 2019. DOI: $10.1080 / 10630732.2019 .1637694$.

[13] Ling, T.Y. \& Chiang, Y.C., Well-being, health and urban coherence-advancing vertical greening approach toward resilience: A design practice consideration. Journal of Cleaner Production, 182, pp. 187-197, 2018. DOI: 10.1016/j.jclepro.2017.12.207.

[14] Blanco, I., Schettini, E., Scarascia Mugnozza, G., Campiotti, C.A., Giagnacovo, G. \& Vox, G., Vegetation as a passive system for enhancing building climate control. Acta Horticulturae, 1170, pp. 555-561, 2017. DOI: 10.17660/ActaHortic.2017.1170.69.

[15] Schettini, E., Vox, G., Blanco, I., Campiotti, C.A. \& Scarascia Mugnozza, G., Green walls for building microclimate control. Acta Horticulturae, 1215, pp. 73-76, 2018. DOI: 10.17660/actahortic.2018.1215.13.

[16] Hunter, A.M., Williams, N.S.G., Rayner, J.P., Aye, L., Hes, D. \& Livesley, S.J., Quantifying the thermal performance of green façades: A critical review. Ecological Engineering, 63, pp. 102-113, 2014. DOI: 10.1016/j.ecoleng.2013.12.021.

[17] Kontoleon, K.J. \& Eumorfopoulou, E.A., The effect of the orientation and proportion of a plant-covered wall layer on the thermal performance of a building zone. Building and Environment, 45, pp. 1287-1303, 2010. DOI: 10.1016/J.BUILDENV.2009.11.013. 
[18] Widiastuti, R., Caesarendra, W., Prianto, E. \& Budi, W.S., Study on the leaves densities as parameter for effectiveness of energy transfer on the green façade. Buildings, 8, pp. 138, 2018. DOI: 10.3390/buildings8100138.

[19] Ip, K., Lam, M. \& Miller, A., Shading performance of a vertical deciduous climbing plant canopy. Building and Environment, 45, pp. 81-88, 2010. DOI: 10.1016/j.buildenv.2009.05.003.

[20] Charoenkit, S. \& Yiemwattana, S., Living walls and their contribution to improved thermal comfort and carbon emission reduction: A review. Building and Environment, 105, pp. 82-94, 2016. DOI: 10.1016/j.buildenv.2016.05.031.

[21] Jim, C.Y. \& He, H., Estimating heat flux transmission of vertical greenery ecosystem. Ecological Engineering, 37, pp. 1112-1122, 2011.

DOI: 10.1016/j.ecoleng.2011.02.005.

[22] Xing, Q., Hao, X., Lin, Y., Tan, H. \& Yang, K., Experimental investigation on the thermal performance of a vertical greening system with green roof in wet and cold climates during winter. Energy and Buildings, 183, pp. 105-117, 2019.

DOI: 10.1016/j.enbuild.2018.10.038.

[23] Olivieri, F., Grifoni, R.C., Redondas, D., Sánchez-Reséndiz, J.A. \& Tascini, S., An experimental method to quantitatively analyse the effect of thermal insulation thickness on the summer performance of a vertical green wall. Energy and Buildings, 150, pp. 132-148, 2017. DOI: 10.1016/j.enbuild.2017.05.068.

[24] Koyama, T., Yoshinaga, M., Maeda, K. \& Yamauchi, A., Transpiration cooling effect of climber greenwall with an air gap on indoor thermal environment. Ecological Engineering, 83, pp. 343-353, 2015. DOI: 10.1016/j.ecoleng.2015.06.015.

[25] Hoelscher, M.T., Nehls, T., Jänicke, B. \& Wessolek, G., Quantifying cooling effects of façade greening: Shading, transpiration and insulation. Energy and Buildings, 114, pp. 283-290, 2016. DOI: 10.1016/J.ENBUILD.2015.06.047.

[26] Blanco, I., Schettini, E. \& Vox, G., Predictive model of surface temperature difference between green façades and uncovered wall in Mediterranean climatic area. Applied Thermal Engineering, 163, pp. 114406, 2019.

DOI: $10.1016 /$ j.applthermaleng.2019.114406.

[27] Peng, L.L.H., Jiang, Z., Yang, X., He, Y., Xu, T. \& Chen, S.S., Cooling effects of block-scale façade greening and their relationship with urban form. Building and Environment, 169, pp. 106552, 2020. DOI: 10.1016/j.buildenv.2019.106552.

[28] Yang, F., Yuan, F., Qian, F., Zhuang, Z. \& Yao, J., Summertime thermal and energy performance of a double-skin green façade: A case study in Shanghai. Sustainable Cities and Society, 39, pp. 43-51, 2018. DOI: 10.1016/j.scs.2018.01.049.

[29] Pérez, G., Rincón, L., Vila, A., González, J.M. \& Cabeza, L.F., Behaviour of green façades in Mediterranean Continental climate. Energy Conversion and Management, 52, pp. 1861-1867, 2011. DOI: 10.1016/j.enconman.2010.11.008.

[30] Perini, K., Ottelé, M., Fraaij, A.L.A., Haas, E.M. \& Raiteri, R., Vertical greening systems and the effect on air flow and temperature on the building envelope. Building and Environment, 46, pp. 2287-2294, 2011. DOI: 10.1016/j.buildenv.2011.05.009.

[31] Sternberg, T., Viles, H. \& Cathersides, A., Evaluating the role of ivy (Hedera helix) in moderating wall surface microclimates and contributing to the bioprotection of historic buildings. Building and Environment, 46(2), pp. 293-297, 2011.

DOI: 10.1016/j.buildenv.2010.07.017.

[32] Convertino, F., Vox, G. \& Schettini, E., Heat transfer mechanisms in vertical green systems and energy balance equations. International Journal of Design \& Nature and Ecodynamics, 14, pp. 7-18, 2019. DOI: 10.2495/DNE-V14-N1-7-18. 
68 Urban Agriculture and City Sustainability II

[33] Convertino, F., Vox, G. \& Schettini, E., Convective heat transfer in green façade system. Biosystems Engineering, 188, pp. 67-81, 2019.

DOI: 10.1016/j.biosystemseng.2019.10.006.

[34] He, Y., Yu, H., Ozaki, A., Dong, N. \& Zheng, S., An investigation on the thermal and energy performance of living wall system in Shanghai area. Energy and Buildings, 140, pp. 324-335, 2017. DOI: 10.1016/j.enbuild.2016.12.083.

[35] Zhang, L. et al., Thermal behavior of a vertical green façade and its impact on the indoor and outdoor thermal environment. Energy and Buildings, 204, pp. 109502, 2019. DOI: $10.1016 /$ j.enbuild.2019.109502.

[36] Larsen, S.F., Filippín, C.S. \& Lesino, G., Thermal simulation of a double skin façade with plants. Energy Procedia, 57, pp. 1763-1772, 2014.

DOI: $10.1016 /$ j.egypro.2014.10.165.

[37] Chen, Q., Li, B. \& Liu, X., An experimental evaluation of the living wall system in hot and humid climate. Energy and Buildings, 61, pp. 298-307, 2013. DOI: 10.1016/j.enbuild.2013.02.030.

[38] Olivieri, F., Olivieri, L. \& Neila, J., Experimental study of the thermal-energy performance of an insulated vegetal façade under summer conditions in a continental mediterranean climate. Building and Environment, 77, pp. 61-76, 2014.

DOI: 10.1016/j.buildenv.2014.03.019. 